\title{
ANALISIS STRATEGI PEMASARAN TERHADAP MINAT NASABAH PADA PERBANKAN DI PEMATANGSIANTAR
}

\author{
1) Sarida Sirait, ${ }^{2)}$ Kalvin Sinaga \\ ${ }^{1}$ Komputerisasi Akuntansi, Politeknik Bisnis Indonesia \\ email: saridasrt@gmail.com \\ ${ }^{2}$ Keuangan \& Perbankan, Politeknik Bisnis Indonesia \\ email: kal.sinaga@gmail.com
}

\begin{abstract}
Financial institutions, both bank and non-bank, which continue to develop in Indonesia will encourage financial institutions to always optimize their marketing activities. One of them is Bank Mandiri in facing competition. One of the strategies of Bank Mandiri is the marketing mix strategy. The formulation of the problem in this study is whether the Marketing Mix strategy affects the interest of Bank Mandiri KC Pematangsiantar customers. The purpose of this study is to determine whether the Marketing Mix affects customer interest in Bank Mandiri KC Pematangsiantar. This research is a type of field research (field research) with a descriptive nature using primary and secondary data, in addition to the data collection methods in this study using observation and interview methods, and this method of analysis using quantitative analysis methods. Based on the results of this study, it shows that the application of marketing strategies uses a marketing mix, the products offered are very varied according to the needs of society for the present and the future, then promotion using personal selling, advertising via television, brochures and others. , publicity with exhibition activities, social service. The marketing strategy that has been implemented has been good in increasing customer interest. Respondents in this study were 97 customers. From the results of data analysis it can be concluded that, there is a significant positive influence between marketing strategy variables $(X)$ on customer interest $(Y)$ at Bank Mandiri Kc Pematangsiantar, the contribution of the influence of marketing strategy variables $(X)$ on customer interest $(Y)$ coefficient of determination (R2) 0.76 shows that $76 \%$ of marketing strategies (X) affect customer interest $(Y)$, while $24 \%$ are influenced by other variables not discussed in this study.
\end{abstract}

Keywords: Marketing strategy, customer interest

\section{PENDAHULUAN}

Sehubungan dengan perkembangan perekonomian di Indonesia, fungsi dan peranan perbankan dimasa ini semakin menduduki tempat terpenting, karena jasa perbankan merupakan penopang hampir seluruh program dan kegiatan pembangunan ekonomi, industri, perdagangan dan dunia usaha maupun jasa- jasa lainnya. Dengan banyaknya jumlah bank yang beroperasi menimbulkan persaingan yang cukup ketat diantara bank dalam menari minat nasabah. Masing-masing bank berupaya untuk memberikan pelayanan sebaik mungkin kepada nasabahnya agar tujuan yang telah ditetapkan dapat dicapai. Dengan diketahuinya keinginan dan kebutuhan nasabah serta lingkungan pemasaran yang memengaruhinya memudahkan bank untuk melakukan strategi guna untuk merebut hati nasabah. (Usman, 2001). Dengan adanya penerapan 
strategi pemasaran yang maksimal,maka diharapkan akan menarik minat masyarakat atau nasabah sehingga mereka bisa mengambil keputusan untuk menabung atau menggunakan produk atau jasa lain yang ada di Bank Mandiri KC Pematangsiantar. Selain itu, Bank Mandiri perlu melakukan sosialisasi secara terus menerus, agar tercipta suatu pemahaman yang baik bagi masyarakat atau nasabah mengenai sistem dan operasional Bank Mandiri. Bank Mandiri merupakan perushaan yang sudah ada sejak tahun 1998 pada awalnya perkembangan bank mandiri sangat pesat sampai akhirnya bank mandiri salah satu bank terbaik diindonesia. dalam hal peningkatan kualitas seluruh perushaan perbankan diindonesia berupaya untuk tetap memimpin pasar. Berdasarkan wawancara yang peneliti lakukan kepada pegawai Bank Mandiri KC Pematangsiantar kegiatan pemasaran yang mereka lakukan tidak begitu banyak. Dalam meningkatkan minat nasabah, bank mandiri tidak menitik beratkan kepada strategi pemasaran. Namun menitik beratkan kepada meningkatkan pelayanan saja. Namun seiring berjalannya waktu dan semakin ketatnya persaingan perbankan membuat bank mandiri harus memikirkan strategi lain dalam meningkatkan minat nasabah. Salah satu yang menjadi strategi Bank Mandiri KC Pematangsiantar yaitu strategi bauran pemasaran (Marketing Mix). Menyikapi hal tersebut, tentunya pelaku bisnis terutama perbankan akan berusaha semaksimal mungkin untuk mempengaruhi perilaku konsumen untuk menjadi mitra maupun konsumen terbaiknya. Pihak perbankan juga dituntut dapat secara jeli memprediksikan perkembangan ekonomi mikro dan makro agar dapat menentukan hasil yang akan dicapai tidak hanya mengoptimalkan pendapatan yang berbasis pelayanan nasabah tetapi bisnis yang berbasis pada pelayanan calon nasabah. Hal ini juga dialami oleh PT.Bank Mandiri,Tbk yang berlokasi di kota Pematangsiantar. Banyak organisasi jasa seperti Bank Mandiri ini melakukan strategi untuk memperluas kapasitas usahanya dimana harus disesuaikan dengan permintaan dan selera konsumen. sehingga para nasabah/ konsumen bertransaksi tidak lagi melihat siapa pegawainya, dan bagaimana pegawai tersebut, tetapi yang mereka lihat adalah bagaimana orang/ pegawai bank tersebut cepat dalam memproses apa yang mereka inginkan. Oleh karena itu, PT.Bank Mandiri dituntut dapat memprediksikan bagaimana para nasabah atau konsumen akan merespon strategi pemasaran yang diterapkan. Agar dapat mencapai sasaran yang diinginkan, peran promosi turut menentukan keberhasilan produk yang perusahaan ciptakan. Strategi pengembangan harus dibangun atas dasar adanya kesinambungan antara deferensiasi produk, saluran distribusi atau tempat yang strategis untuk melayani konsumen, proses dan bukti fisik yang saling mendukung.

Berdasarkan latar belakang diatas maka rumusan masalah dalam penelitian ini adalah Apakah strategi Marketing Mix berpengaruh terhadap minat nasabah Bank. Tujuan dari penelitian ini adalah untuk mengetahui hubungan penerapan marketing mix dengan minat nasabah pada Bank Mandiri KC Pematangsiantar.

\section{Tinjauan Pustaka}

Pemasaran adalah pekerjaan rumah yang harus dikerjakan manajemen untuk menilai kebutuhan, mengukur tingkat dan intensitasnya, dan menentukan apakah ada peluang yang mengutungkan (Kasmir \& others, 2015). Pemasaran berlanjut selama hidup produk, berusaha mendapatkan konsumen baru dan mempertahankan konsumen dengan tetap mempelajari dan 
meningkatkan kinerja pemasaran. Jadi, penjualan dan periklanan hanyalah bagian dari marketing mix - sekumpulan peralatan pemasaran yang bekerja bersama untuk mempengaruhi pasar (Subagyo, 2010). Untuk menerangkan defenisi itu , kita akan membahas istilah-istilah penting berikut ini: Kebutuhan (needs), keinginan (wants), danpermintaan (demand), 9 produk (product), dan jasa (service), nilai (value), kepuasan (satisfactions), dan kualitas (quality), pertukaran (exchange), transaksi (transactions), dan relasional (relationship), dan pasar (markets). Penjelasan dari beberapa istilah diatas antara lain adalah: a. Kebutuhan.

Kebutuhan manusia adalah sesuatu yang dirasakan dirasakan ingin diproleh oleh seseorang. b. Keinginan. Keinginan manusia adalah kebutuhan yang terjadi karena pengaruh kebudayaan dan inividualistis seseorang. Keinginan dibentuk oleh masyarakat dan di kemukakan sebagai sesuatu yang menjadi pemuas kebutuhan tersebut. Orang biasanya memiliki keinginan yang tidak terbatas tapi sumber daya yang terbatas. Ketika didukung oleh daya beli, keinginan berubah menjadi permintaan. c. Permintaan Adalah keinginan terhadap produk tertentu dan disertai oleh kemampuan untuk membeli produk itu. d. Produk dan Jasa. Produk merupakan sesuatu yang ditawarkan ke pasar untuk diperhatikan, dimiliki dan dibeli oleh konsumen untuk mememuhi kebutuhannya. Sebagai tambahan bagi barang berwujud, produk mencakup jasa yaitu aktivitas atau manfaat dari barang jualannya secara esnsial tidak berwujud dan tidak menghasilkan kepemilikan atas apapun. Contohnya ialah jasa perbankan, hotel dan perbaikan rumah. Banyak penjual membuat kesalahan dengan lebih memperhatikan ke produk spesifik yang mereka tawarkan dan bukannya ke manfaat yang di tawarkan oleh produk-produk tersebut. Mereka lupa bahwa produk hanyalah alat untuk memecakan permasalahan konsumen. Penjual seperti itu akan mengalami masalah bila produk baru muncul dan dapat memenuhi kebutuhan konsumen dengan lebih baik atau lebih murah. Konsumen dengan kebutuhan sama akan menginginkan produk baru tersebut. e. Pertukaran Adalah tindaka seseorang untuk memproleh sesuatu hal dan memberikan hal lain sebagai gantinya. Bila pertukaran merupakan konsep inti pemasaran. f. Nilai, kualitas, dan kepuasan Nilai bagi pelanggan atau value (customer value) merupakan perbedaan antara nilai yang dinikmati pelanggan karna memiliki serta menggunakan suatu produk dan biaya untuk memiliki produk tersebut. Sejalan dengan itu The American Society for Quality Control mendefenisikan kualitas sebagai sifat dan karakteristik total produk atau jasa yang berhubungan dengan kemampuannya memuaskan kebutuhan pelanggan. Kualitas dimulai dengan kebutuhan pelanggan dan di akhiri dengan kepuasan pelanggan. g. Pasar. Pasar adalah sekumpulan pembeli potensial. Ukuran pasar tergantung pada jumlah orang yang menunjukkan kebutuhan, mempuyai sumber daa yang melakukan pertukaran dan persediaan menawarkan sumber daa dalam pertukaran itu untuk mendapkan apa yang mereka inginkan.

Segmentasi, Targeting, Positioning, dan Bauran Pemasaran.

(Khoir, 2016), dikatakan bahwa proses dari segmentasi pasar, pemposisian dan bauran pemasaran sangat erat kaitannya. Bagianbagian dari pada proses segmentasi secara tidak langsung berhubungan dengan pemposisian suatu produk atau jasa dan pemposisian berhubungan dengan bauran pemasaran. Sehingga jika Mendifinisikan Dasar-dasar Alternatif Segmentasi Memilih Dasar Terbaik untuk Segmentasi Mengidentifikasikan dan Menyeleksi Segmen Pasar, Pengembangan positioning untuk target pasar, Pengembangan bauran pemasaran untuk berbagai target pasar dipadukan 
ketiganya maka perusahaan akan siap bersaing dan memperoleh ceruk pasar yang lebih besar. Menetapkan Pasar Sasaran (Kasmir \& others, 2015). Setelah selesai melakukan segmentasi pasar, maka diproleh beberapa segmen yang diinginkan. Pertimbangan untuk memilih segmen adalah besarnya segmen yang akan dipilih dan luasnya segmen. Setelah teridentifikasikan jumlah serta ukuran dan luasnya segmen yang ada, selanjutnya yang harus dilakukan adalah menetapkan pasar sasaran yang diinginkan, artinya melakukan evaluasi dan penilaian terhadap segmen pasar yang telah ditetapkan sebelumnya. Menetapkan segmen pasar dengan cara membuat kriteri-kriteri sesuai dengan kondisi pasar sasaran. Penetapan pasar ini antara lain(Kasmir \& others, 2015) :

1. Evaluasi segmen pasar yang meliputi: a. Ukuran dan pertumbuhan segmen seperti data tentang usia nasabah, pendapatan, jenis kelamin, atau gaya hidup dari setiap segmen. b. Membuat struktur segmen yang menarik dilihat dari segi perolehan laba. c. Sumberdaya yang dimiliki oleh bank serta memerhatikan energi yang dimiliki bank, misalnya sumber daya manusia.

2. Memilih segmen, yaitu menentukan segemen yang memiliki dampak positif terhadap laba atau segmen yang mendukung kinerja bank. Pemilihan segmen dapat dilakukan dengan cara: a. Pemasaran serba sama, melayani semua pasar dan tawaran pasar dalam arti tidak ada perbedaan. Mencari apa yang sama dalam kebutuhan konsumen. Biasanya untuk produk massal seperti tabungan untuk semua orang, baik usaha, pendapatan maupun wilayah.

Beberapa bentuk pemasaran yang bisa diterapkan misalnya a. pemasaran serba sama adalah hemat biaya. b. Pemasaran serba aneka, merancang tawaran untuk semua pendapat, tujuan atau kepribadian. Misalnya, beda desain seperti untuk industri mobil. Untuk pasarini memerlukan biaya tinggi. c. Pemasaran terpadu, khusus untuk sumberdaya manusia yang terbatas. Menentukan Posisi
Pasar (Market Positioning) (Khoir, 2016) menentukan posisi pasar, yaitu menentukan posisi yang kompetitif untuk produk atau suatu pasar.

Secara garis besar dalam melakukan kegiatan promosi dikelompokkan menjadi 4 kegiatan utama, yaitu (Ferdinand, 2002) : a) Periklanan (advertising), pembuatan iklan untuk promosi merupakan salah satu upaya yang sangat efektif dalam kegiatan promosi. b) Promosi penjualan (sales promotion) Promosi penjualan ini bertujuan untuk meningkatkan volume penjualan. c) Publisitas (publicity) Melakukan promosi berupa pameran atau kegiatan-kegiatan lain yang sifatnya publikasi. Kegiatan publisitas dapat meningkatkan nama baik bank dimata nasabah. Kegiatan publisitas dapat dilakukan melalui ikut pameran, ikut kegiatan amal, ikut bakti sosial serta sponsorship kegiatan. Tujuannya agar nasabah mengenal lebih dekat dan melalui kegiatan tersebut nasabah akan selalu ingat bank tersebut sehingga diharapkan akan menarik lebih banyak nasabah. d) Penjualan pribadi (personal selling) Kegiatan promosi dalam bentuk percakapan dengan satu calon nasabah atau lebih yang ditunjukkan untuk menciptakan penjualan. Selain itu dapat memperoleh informasi mengenai kelemahan produk dan keluhan nasabah yang disampaikan secara langsung oleh nasabah kepada pihak bank (Maharsi \& Mulyadi, 2007). Mereka sangat mempengaruhi kualitas jasa yang diberikan oleh perusahaan sehingga perusahaan harus memiliki kehati-hatian untuk pengambilan keputusan tentang salah satu bauran pemasaran ini. Kehati-hatian ini dilakukan sejak seleksi, training, motivasi, dan penerapan fungsi manajemen sumber daya manusia lainnya di perusahaan. Manusia (people) di dalam perusahaan harus memiliki tanggung jawab terhadap kelangsungan hidup perusahaan sehingga manusia di dalam perusahaan dapat bertindak sebagai marketer sehingga dapat survive di tengah persaingan, perusahaan tidak hanya berfokus pada pemegang saham saja tetapi juga berfokus memberikan kepuasan yang berkelanjutan untuk orang-orang yang ada di dalam perusahaan agar dapat bekerja secara optimal 
misalnya kompensasi, fasilitas kesehatan dan sebagainya (Subagyo, 2010).

Minat menurut bahasa keinginan hati akan sesuatu hal atau hasrat untuk memiliki sesuatu hal. Minat juga dapat diartikan sebagai motivasi seorang untuk memperoleh sesuatu.(Maharsi \& Mulyadi, 2007). Demikian juga dalam dunia perbankan, motivasi seseorang untuk datang dan membeli produk perbankan ada berbagai macam. Salah satu penyebab timbulnya minat nasabah terhadap suatu produk berbankan dapat dipengaruhi oleh kualitas dari produk tersebut atau kemampuan produk tersebut untuk memenuhi kebutuhan nasabah. Seseorang yang menaruh minat terhadap suatu objek akan merasakan adanya kebutuhan penting bagi kehidupannya, dan melakukan usahausaha yang teguh tanpa adanya paksaan dari orang lain. Untuk mendapatkan objek yang diminatinya tersebut, subjek harus mengidentifikasikan sejauh mana keuntungan dan kebutuhan yang diinginkan dari objek tersebut, bagaimana cara memenuhi keinginannya dan kemudian disikapi dengan membuat keputusan. Dalam pengambilan keputusan ada tahapan yang dilalui minat seseoang (Maharsi \& Mulyadi, 2007), yaitu: a. kesadaran (awareness), pada tahap ini perusahaan melakukan promosi agar konsumen mengenal produk dan menyadari bahwa produk tersebut ada. b. Pengetahuan (knowledge), perusahaan melakukan promosi yang informatif agar konsumen secara memiliki pengetahuan yang banyak atas produk c. Suka (Liking), nasabah suka dan ingin memiliki produk itu d. menjadikan produk sebagai pilihan, dalam hal ini nasabah sudah mengambil keputusan untuk memilih suatu produk yang dia sukai. e. yakin dengan produk, nasabah yakin terhadap produk itu dan berniat memperkenalkan kepada orang lain f. pembelian (purchase), konsumen sudah mengambil keputusan untuk membeli produk.

Faktor yang mempengaruhi minat.

Adapun faktor yang mempengaruhi minat yaitu sebagai berikut: a. Faktor dorongan dari dalam Faktor ini merupakan rasa ingin tahu atau dorongan untuk menghasilkan sesuatu yang baru dan berbeda. Dorongan ini dapat membuat seseorang berminat untuk melakukan aktivitas yang menantang. b. Faktor motif sosial Faktor ini bisa diartikan sebagai suatu minat dalam upaya mengembangkan diri dari dalam ilmu pengetahuan, yang mungkin diilhami oleh hasrat untuk mendapatkan kemampuan dalam bekerja, atau adanya hasrat untuk memperoleh penghargaan dari keluarga atau teman. c. Faktor emosional Faktor ini merupakan minat yang berkaitan dengan perasaan dan emosi. Misalnya, keberhasilan akan menimbulkan perasaan puas dan dapat meningkatkan minat, sedangkan kegagalan dapat menghilangkan minat seseorang (Maharsi \& Mulyadi, 2007).

\section{METODE PENELITIAN}

Penelitian ini dilakukan di salah satu perbankan di Pematangsiantar, yaitu Bank Mandiri KC. Pematangsiantar. Penelitian ini bersifat kuantitatif. Populasi dari penelitian ini adalah nasabah Bank Mandiri KC. Pematangsiantar. Teknik pengambilan sampel dalam penelitian ini menggunakan slovin sehingga diperoleh sampel sebesar 97 responden. Teknik Pengumpulan data yang dilakukan penulis adalah dengan menyebarkan kuesioner serta melakukan wawancara. Data yang diperoleh dari hasil penyebaran kuesioner tersebut terlebih dahulu diuji validitas dan reliabilitasnya sehingga data tersebut mumpuni untuk diuji lebih lanjut. Teknik analisis yang digunakan penulis adalah pengujian data dengan menggunakan regresi linear atau uji t.

\section{HASIL DAN PEMBAHASAN Pengujian Instrumen Penelitian}

Tingkat kevalitan instrumen diketahui melalui uji validitas dengan menggunakan SPSS yang dilakukan terhadap kuesioner dengan butir pertanyaan melalui sampel uji coba validitas instrumen sebanyak 97 responden. Dalam penelitian ini besarnya $r$ tebel dengan tingkat signifikan 5\% untuk jumlah responden yang berjumlah 97 responden adalah sebesar 0,1975. Jika $r$ hitung $>\mathrm{r}$ tabel, maka item pernyataan dapat dikatakan valid, sebaliknya jika $r$ hitung $<r$ tabel maka item pernyataan dikatakan tidak valid. 
Tingkat kevalidtan instrumen diketahui melalui uji validitas dengan menggunakan SPSS yang dilakukan terhadap kuesioner dengan butir pertanyaan melalui sampel uji coba validitas instrumen sebanyak 97 responden. Dalam penelitian ini besarnya $r$ tebel dengan tingkat signifikan 5\% untuk jumlah responden yang berjumlah 97 responden adalah sebesar 0,1975. Jika $r$ hitung $>\mathrm{r}$ tabel, maka item pernyataan dapat dikatakan valid, sebaliknya jika $r$ hitung $<r$ tabel maka item pernyataan dikatakan tidak valid. Pengujian terhadap Reliabilitas adalah Nilai Cronbach's Alpha untuk Instrumen Strategi Pemasaran adalah $0,73>\mathrm{r}$ tabel 0,1975 menandakan bahwa instrumen reliabilitas tersebut realibel. Cronbach's Alpha untuk Instrumen minat adalah $0,800>$ $\mathrm{r}$ tabel 0,1975 meandakan bahwa instrumen reliabel karena sudah memenuhi batas 0,60 $(0,800>0,60)$ sehingga dapat digunakan untuk penelitian selanjutnya. Pengujian selanjutnya adalah uji normalitas data dengan menggunakan One-Sample KolmogorovSmirnov Test. Dari hasil uji tersebut diperoleh Asymp.sig.(2-tailed) sebesar 0,20 . Asymp.sig.(2-tailed) merupakan pengujian untuk memastikan bahwa distribusi teramati tidak akan menyimpang secara signifikan dari distribusi yang diharapkan. Asymp.sig.(2tailed) sebesar 0,20 dan menggunakan level of signifikan 0,05 maka dapat disimpulkan bahwa data mengikuti distribusi normal karena $0,20>0,05$.

\section{Koefisien Determinasi $\left(\mathbf{R}^{\mathbf{2}}\right)$}

Uji koefisien determinasi digunakan untuk mengetahui persentase sumbangan pengaruh variable strategi pemasaran terhadap minat nasabah. Tabel diatas menampilkan nilai $\mathrm{R}$ yang merupakan simbol dari nilai koefisien korelasi. Pada data dibawah ini nilai korelasi adalah 0,873 . Nilai ini dapat diinterpretasikan bahwa hubungan kedua variable penelitian ada di kategorikan kuat. Melalui tabel dibawah ini juga diperoleh nilai R Square atau koefisien determinasi (KD) yang menunjukkan seberapa bagus modelregresi yang dibentuk oleh interaksi variable bebas dan variable terikat. Nilai KD yang diproleh adalah 0,76 atau $76 \%$ yang dapat ditafsirkan bahwa variable bebas $\mathrm{X}$ memiliki pengaruh konribusi sebesar $76 \%$ terhadap variable $\mathrm{Y}$ dan $24 \%$ lainnya adalah dipengaruhi oleh faktor-faktor lain diluar variable $X$ yang tidak diteliti oleh peneliti.

\section{Pengujian Hipotesis (Uji t)}

Tabel Hasil Uji Koefisien Determinasi Model Summary

\begin{tabular}{|l|r|l|c|}
\hline Model & $\mathrm{R}$ & $\mathrm{R}$ Square & $\begin{array}{c}\text { Adjusted } \mathrm{R} \\
\text { Square }\end{array}$ \\
\hline 1 &, $873^{\mathrm{a}}$ &, 762 &, 759 \\
\hline
\end{tabular}

Sumber : Pengolahan SPSS

Uji t atau persial pada dasarnya digunkan utuk menunjukkan pengaruh satu variable independen secara individual dalam menerangkan variable dependen. Besarnya angka $t$ tabel dengan ketentuan sig 0,05 dan jumlah responden sebesar 97 sehingga diproleh ketentuan nilai t tabel sebesar 1,985

1) Jika nilai signifikan pengujian $<0,05$ berati Ho ditolak, artinya Ho ditolak dan $\mathrm{Ha}$ diterima, sehingga hipotesis yang dirumuskan terbukti kebenarannya.

2) Jika nilai signifikan pengujian $>0,05$ berarti Ho diterima, artinya Ho diterima dan Ha ditolak, sehingga hipotesis yang ddirumuskaan tidak terbukti kebenarannya. Dari hasil output diproleh nilai signifikansi dari variabel strategi pemasaran adalah 0.000 $<0,05$ sehingga dapat disimpulkan bahwa $\mathrm{Ha}$ diterima yang artinya strategi pemasaran pada Bank Mandiri KC Pematangsiantar berpengaruh positif signifikan terhadap minat nasabah. Semakin tinggi strategi pemasaran yang dilakukan Bank Mandiri Kc 
Pematangsiantar maka akan semakin tinggi pula minat nasabah yang diproleh.

Tabel. Hasil Uji T

\section{Coefficients}

\begin{tabular}{|c|c|c|c|c|}
\hline \multirow[b]{2}{*}{ Model } & \multicolumn{2}{|c|}{ Unstandardized } & \multirow{2}{*}{$\begin{array}{l}\text { StandardizC } \\
\text { oefficients }\end{array}$} & \multirow[b]{2}{*}{ Sig. } \\
\hline & B & $\begin{array}{l}\text { Std. } \\
\text { Error }\end{array}$ & & \\
\hline (Constant) &,- 808 & 1,686 & & 633 \\
\hline $\begin{array}{l}\text { srategi } \\
\text { pemas }\end{array}$ & ,965 & ,055 & 873 & 000 \\
\hline
\end{tabular}

Sumber : Pengolahan SPSS

\section{Pembahasan}

Pemasaran merupakan suatu proses mempersepsikan, memahami, menstimulasi dan memenuhi kebutuhan pasar sasaran yang dipilih secara khusus dengan menyalurkan sumber-sumber sebuah organisasi untuk memenuhi kebutuhan-kebutuhan tersebut. Sehingga, pemasaran merupakan proses penyelarasan sumber-sumber sebuah organisasi terhadap kebutuhan pasar. Pemasaran memberikan perhatian pada hubungan timbal balik yang dinamis antara produk-produk dan jasa-jasa perusahaan, keinginan dan kebutuhan konsumen, dan kegiatan-kegiatan para pesaing. Berdasarkan wawancara dengan Direct Sales Mandiri KC Pematangsiantar, berpendapat bahwa strategi yang paling tepat adalah di unsur promosi. Karena pihak pemasar/bank Mandiri lebih mudah untuk berkomunikasi dengan nasabah baik secara langsung maupun tidak langsung serta lebih efektif dalam melakukan kegiatan pemasaran. Kegiatan promosi yang dilakukan berupa memberikan brosur kepada masyarakat, memberikan informasi dengan presentasi ke berbagai instansi/perusahaan, serta melakukan penjualan dengan personal selling. Metode tersebut diyakini paling tepat karena dapat melihat langsung nasabah yang akan membeli produk. Pemasar juga sekaligus dapat melihat bagaimana karakteristik, respon serta sikap nasabah saat diberikan penjelasan mengenai produk yang ditawarkan. Saat melakukan strategi personal selling, pemasar Mandiri KC Pematangsiantar tidak memaksakan nasabah untuk membeli produk. Karena pihak pemasar sudah memahami sifat nasabah apabila menawarkan dengan cara memaksa nasabah tidak akan suka dan cenderung menjadi tidak tertarik. Pembahasan Hasil penelitian ini menunjukan adanya pengaruh yang positif dari semua variabel bebas yang diteliti terhadap variabel terikat. Artinya minat nasabah Bank Mandiri KC Pematangsiantar dipengaruhi oleh faktor produk, promosi, dan pelayanan bank. Di antara faktor-faktor tersebut, pelayanan bank merupakan faktor yang memberi pengaruh lebih dominan terhadap pembentukan minat nasabah. Temuan ini dimungkinkan karena pada hakekatnya kepuasan konsumen sangat dipengaruhi oleh pelayanan yang di terima dari pemberi jasa. Sebagus apapun produk yang ditawarkan dan promosi yang dilakukan, akan tidak berarti apa-apa bagi konsumen ketika pelayanan yang didapatkan tidak seperti yang diharapkan. Hal ini tidak terlepas dari karakteristik jasa yang tidak berwujud, tidak bisa dimiliki, serta produksi dan konsumsinya terjadi pada saat bersamaan. Selain itu, pemberian pelayanan sebenarnya merupakan upaya untuk memenuhi janji yang diberikan oleh pemasar dalam kegiatan promosi. Pelayanan yang berkualitas akan membuktikan pemasar tidak over promise and under deliver. Pelayanan yang sesuai dengan harapan nasabah akan memberikan kepuasan bagi mereka, dan sebaliknya jika kurang dari yang diharapkan, akan menimbulkan ketidakpuasan. Berdasarkan analisis data yang telah diuji dalam penelitian ini, maka dapat dijelaskan bahwa ada pengaruh positif signifikan antara strategi pemasaran terhadap minat nasabah,. Jika strategi pemasaran semakin meningkat, maka minat nasabah 
akan semakin tinggi. Hal ini terbukti dari hasil analisis uji $\mathrm{t}$ yang menunjukkan nilai $\mathrm{t}$ hitung sebesar 17,421 dengan taraf signifikan sebesar 0,000 . Adanya pengaruh yang positif antara strategi pemasaran terhadap minat nasabah juga ditunjukkan oleh hasil model summary pada uji koefisien determinasi yang menghasilkan nilai $\mathrm{R}$ Square sebesar 0,762 atau sebesar 76,2 \% strategi pemasaran mempengaruhi minat nasabah pada Bank Mandiri Kc Pematangsiantar. Hal ini didukung oleh beberapa peneliti terdahulu yakni (Lolo, n.d.) yang berjudul pengaruh marketing mix terhadap keputusan Konsumen yang menabung pada Pt.bank mandiri(persero)tbk.,cabang makassar kartini. Mengatakan bahwa ada pengaruh yang signifikan antara marketing mix terhadap keputusan Konsumen yang menabung pada Pt.bank mandiri (persero) tbk., cabang makasar kartini. Adapun Diana Qoudarsi (2011) dengan penelitian yang berjudul pengaruh penerapan strategi pemasaran dan komunikasi Terhadap minat nasabah untuk menabung di bmt Cirebon. Mengatakan bahwa ada pengaruh yang signifikan antara strategi pemasaran terhadap minat nasabah di bmt Cirebon. Hal ini terbukti dari hasil peelitian yang menunjukkan uji $\mathrm{t}$ berpengaruh positif signifikan terhadap minat nasabah sebesar 0,000. Kemudian penelitian Harmita Dewiny Siregar (2010) dalam penelitiannya berjudul Analisis Bauran Pemasaran Dalam Mempengaruhi Keputusan Nasabah Tabungan Simpedes Pada PT Bank Rakyat Indonesia (Persero) Tbk Kantor Cabang Binjai. Hasil penelitiannya menunjukkan bahwa variabel produk, harga, tempat promosi, orang, proses dan bukti fisik berpengaruh positif dan signifikan terhadap keputusan nasabah Simpedes pada PT. Bank Rakyat Indonesia (Persero) Tbk Kantor Cabang Binjai.

\section{KESIMPULAN}

Kesimpulan dari hasil penelitian " Analisis Strategi Pemasaran Terhadap Minat Nasabah Bank Mandiri Kc Pematang siantar" adalah sebagai berikut:
1. Berdasarkan analisis yang telah diuraikan diatas, diketahui bahwa variabel independen yakni strategi pemasarn menggunakan strategi bauran pemasaran $(\mathrm{X})$ berpengaruh positif terhadap variabel minat nasabah (Y). Hal ini didapatkan berdasarkan nilai R Square sebesar 0,76 atau $76 \%$ yang dapat ditafsirkan bahwa variable bebas $\mathrm{X}$ memiliki pengaruh konribusi sebesar $76 \%$ terhadap variable $\mathrm{Y}$

2. Strategi pemasaran yang dilakukan oleh Mandiri Kc Pematangsiantar tidak lepas dari unsur-unsur bauran pemasaran/ marketing mix, yang terdiri dari : Strategi Produk, Strategi Harga, Strategi Tempat dan Strategi Promosi. Dari strategi promosi tersebut, terbagi menjadi beberapa media seperti periklanan, promosi penjualan, publisitas, personal selling dan referensi dari teman. Dengan perencanaan promosi yang matang akan membantu Mandiri Kc Pematangsiantar dalam meningkatkan minat nasabah.

3. Mandiri Kc Pematangsiantar dalam meningkatkan minat nasabah menggunakan strategi pemasaran marketing mix, dengan metode promosi yang paling dominan. Alat promosi melalui media cetak brosur dan personal selling.

\section{REFEREENSI}

Ferdinand, A. (2002). Kualitas Strategi Pemasaran: Sebuahstudi Pendahuluan. Jurnal Sains Pemasaran Indonesia (Indonesian Journal of Marketing Science), 1(1), 107-119.

Kasmir, S. E., \& others. (2015). Studi Kelayakan Bisnis: Edisi Revisi. Prenada Media.

Khoir, M. (2016). MENGIDENTIFIKASI SEGMEN PASAR DAN MEMILIH PASAR SASARAN.

Lolo, I. N. T. (n.d.). Andi. 2011. Pengaruh Strategi Marketing Mix Terhadap Keputusan Konsumen Yang Menabung Pada PT. Bank Mandiri (Persero) TBK, Cabang Makasar Kartini.

Maharsi, S., \& Mulyadi, Y. (2007). Faktor- 
Faktor yang Mempengaruhi Minat Nasabah. Jurnal Akuntansi Dan Keuangan, 9(1), 18-28.

Subagyo, A. (2010). Marketing In Business.

Jakarta: Mitra Wacana Media.

Usman, R. (2001). Aspek-aspek hukum perbankan di Indonesia. Gramedia Pustaka Utama. 